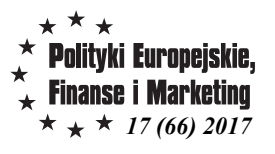

Jolanta Zralek

Uniwersytet Ekonomiczny w Katowicach

\title{
WHO IS A SUSTAINABLE CONSUMER? IN SEARCH OF A NEW HUMAN CONCEPT IN SUSTAINABLE ECONOMY
}

\section{Kim jest zrównoważony konsument? W poszukiwaniu nowej koncepcji czlowieka w zrównoważonej gospodarce}

Sposób, w jaki ekonomiści postrzegajq i interpretuja zachowania jednostek przektada się bezpośrednio na narzędzia wykorzystywane $w$ polityce zrównoważonego rozwoju (PZR). Ich skuteczność, a zatem możliwość osiagnięcia celów zrównoważenia zależy bowiem od tego jak dobrze przyjęte założenia odwzorowuja rzeczywiste mechanizmy ludzkich zachowań. W miare dojrzewania koncepcji ZR dla ekonomistów ekologicznych coraz bardziej oczywisty stawat sięfakt, $\dot{z}$ e wskazanego warunku nie jest $w$ stanie spetnić neoklasyczna koncepcja homo oeconomicus. Zgodnie z tym nurtem model neoklasyczny ani nie odzwierciedla zasad funkcjonowania zrównoważonego spoleczeństwa, ani nie tlumaczy zrównoważonych zachowań jednostek. $W$ konsekwencji szczególne zainteresowanie ekonomistów ekologicznych skupiło się na analizie $i$ krytyce modelu homo oeconomicus oraz na szukaniu możliwości badź to uzupetnienia tej wizji, bądź jej calkowitej zmiany. Celem tego artykułu jest wyjaśnienie istotnych elementów krytyki koncepcji homo oeconomicus i opisanie na tym tle nowych koncepcji czlowieka zaproponowanych przez przeciwników podejścia neoklasycznego.

Słowa kluczowe: koncepcja człowieka, ekonomia ekologiczna, zrównoważony rozwój, homo oeconomicus

\section{Introduction}

Although the concept of sustainable development emerged already in early 1970s as a reaction to the first Club of Rome rapport ${ }^{1}$ it still evolves being a subject of heated debates not only among politicians, but also, and maybe even primarily among economists all over the world. The rising interest of sustainability issues resulted in emergence of a new approach called ecological economics (EE). Representatives of this school of thought, as one of the core topics started to investigate a conception of humans in sustainable society. In fact, this problem was becoming more and more urgent since the concept of sustainable consumption (SC) was introduced. It took place during United Nations Conference on Environment and Development (known as Rio Summit or Earth Summit) in 1992. It is worth to emphasize that one of the final conference documents Agenda 21, provides many references to SC, as well as crucial recommendations like the general statement, that there is a need to change unsustainable consumption patterns by

\footnotetext{
${ }^{1}$ D. H. Meadows, D. L. Meadows, J. Randers, W. Behrens: The Limits to Growth. UNIVERSE BOOKS, New York 1972.
} 
developing national policies and strategies ${ }^{2}$. Both implementation of sustainable strategies and achieving their desired effects require a change in perceiving human as an economic actor. More precisely the image of person, who is willing to follow sustainability rules, thus freely engages in solving environmental and social problems significantly departs from commonly accepted concept of homo oeconomicus introduced and well established by neoclassical economists.

This article seeks to explain the vital points of critique of homo oeconomicus concept and to describe on this background the new conceptions introduced by the opponents of neoclassical approach. To achieve these goals we conducted a query of literature concerning topics of sustainability and ecological economics. Accordingly the article is structured as follows: first (in section 1) we explain the main sustainable issues discussed in the context of ecological economics, subsequently (in section 2) we introduce the brief critical review of neoclassical model of human actor, finally (in the 3rd section) we enumerate and describe new conceptual frameworks which emerged as a results of ecological economists inquiry.

\section{Sustainable approach in economy}

Within the achievements of mainstream economics (mainly neoclassical one), the scientific interest on environmental topics led to the emergence of environmental economics ${ }^{3}$. However, a part of scholars (as they started to engage deeper into sustainability issues) concluded that explanations offered by neoclassical approach, even if they were modified accordingly to revealed social and environmental problems, failed in clarifying sustainable economy rules. The opportunity to go beyond mainstream economics was also reinforced by scientific development in biology and ecology initiated in 1960s. First it made environmental problems more visible, second revealed their sources, which became more obvious to the public opinion ${ }^{4}$. In consequence the new approach - ecological economics, started to perceive economy and humans as a part of an encompassing ecological whole governed by natural processes. Ecological economists adapted sustainability as the subject of their investigations and concentrated all the research around the question of how to achieve sustainable development ${ }^{5}$. Simultaneously, in line with the statement of Söderbaum ${ }^{6}$ that "it is more important to protect the environment than to protect neoclassical paradigm", they started to criticize neoclassical approach by pointing out its shortcomings. From their perspective causeand-effect relationship between current environmental crisis and economic activities

\footnotetext{
2 Agenda 21, p. 18, https://sustainabledevelopment.un.org/content/documents/Agenda21.pdf [accessed: 25.01.2017].

${ }^{3}$ G. Munda: Environmental Economics, Ecological Economics, and the Concept of Sustainable Development, "Environmental Values" 6 1997, pp. 213-233.

${ }^{4}$ I. Røpke: The early history of modern ecological economics, "Ecological Economics" no. 50/2004, pp. 298299.

5 M. Faber, T. Petersen, J. Schiller: Homo oeconomicus and homo politicus in Ecological.Economics, "Ebological Economics" no. 40/2002, p. 323; H.E. Daly, J. Farley: Ecological Economics. Principles and Applications. ISLAND PRESS, Washington DC 2004, pp. 7-8; T.M. Waring: New Evolutionary Foundations: Theoretical Requirements for a Science of Sustainability, "Ecological Economics" no. 69/2010, pp. 718-719.

${ }^{6}$ P. Söderbaum: Values, ideology and politics in ecological economics, "Ecological Economics" no. 28/1999, p. 162.
} 
driven by neoclassical assumptions is obvious ${ }^{7}$. To proof this conviction ecological economists have pointed at the existence of distributional injustice, global poverty and burdening the poor countries with a problem of environmental degradation. Additional arguments supporting EE assumptions derive from the outcomes of research conducted by Easterlin ${ }^{8}$ who revealed that in well developed countries an economic growth (so strongly required by neoclassical school) doesn't increase human happiness? ${ }^{9}$. The significant part of critical considerations was also connected with calls for widening the understanding of the human being beyond the narrow frames of homo oeconomicus.

\section{Critique of homo oeconomicus model in the light of sustainability research}

Although the father of modern economics A. Smith argued that the main drivers of human behaviors are both empathy and egoism ${ }^{10}$, his scientific successors concentrated solely on this second stimulus while developing Smith's concept of human actor named homo oeconomicus. Accordingly, A. Marshall argued that humans as self-interested and perfectly rational entities are driven by their pursuit of utility maximization ${ }^{11}$. Expected utility theory introduced afterwards by J. Von Neumann and O. Mogenstern added to the model of homo oeconomicus the assumption that people have stable and consistent preferences as well as they use all the market information to assess both utility itself and the possibility of its occurrence ${ }^{12}$. A belief that individual is able to gather and instantly use all market information led J. Muth to the conclusions which resulted in rational expectations hypothesis. According to this hypothesis all human's expectations are correct i.e. they don't differ from rational ones ${ }^{13}$.

In consequence mainstream economics created the image of selfish utility maximizer who is aware of his preferences, perfectly anticipates the future and whose unlimited knowledge allows to undertake fully rational decisions. Considering the main assumptions of sustainable development like intra- and intergenerational justice or the relation of human being with nature, nobody can doubt that for ecological economists homo oeconomicus model is unacceptable, at least in its unchanged version. Appealing to the acquis of behavioral economics, namely concept of bounded rationality introduced

\footnotetext{
${ }^{7}$ C. Gendron: Beyond Environmental and Ecological Economics: Proposal for an Economic Sociology of the Environment, "Ecological Economics" no. 105/2014, p. 241.

${ }^{8}$ R. A. Esterlin: Will Raising the Incomes of all Increase the Happiness of All? "Journal of Economic Behavior and Organization" vol. 27/1995, pp. 35-47.

${ }^{9}$ C. L. Spash: Social Ecological Economics: Understanding the Past to See the Future, "American Journal of Economics and Sociology" vol. 70 no. 2/2011, p. 359.

${ }^{10}$ A. Smith: The Theory of Moral Sentiments, DOVER PUBLICATIONS, INC Mineola, New York 2012, https://books.google.pl/books?id=2iV_vnHmdUEC\&printsec $=$ frontcover\&hl=pl\#v=onepage\&q\&f [accessed: 24.02.2017].

${ }^{11}$ J. Kraciuk: Paradygmat homo oeconomicus w aspekcie rozwoju ekonomii heterodoksyjnej, „Prace Naukowe Uniwersytetu Ekonomicznego We Wrocławiu. Ekonomia" nr 401/2015, pp. 212-213.

${ }^{12}$ D. Schiliro: Bounded rationality: Psychology, economics and the financial crises, "Theoretical and Practical Research in Economic Fields" vol. IV issue 1(7)/2013, p. 98.

${ }^{13}$ J. F. Muth: Rational Expectations and the Theory of Price Movements, "Econometrica" vol. 29 no. 3/1961, pp. 315-335; J. Kraciuk: Paradygmat..., op. cit.; A. Kirman: Is it rational to have rational expectations? "Mind \& Society" no. 13/2014, p. 35.
} 
by Simon ${ }^{14}$, and further developed by Smith $^{15}$ ecological economists state that human actor is not able to gather and process all market information thus can't be fully rational. In fact todays unstable, constantly changing market surroundings cause uncertainty which may lead to spontaneous, emotional, unconsidered and even mindless actions. Furthermore as argue Bina and Guedes $\mathrm{Vaz}^{16}$, egoistical behavior of homo oeconomicus stays in conflict with the need to promote core values of sustainability: altruism and widely understood responsibility - for others, for future generations and for the environment. Apart from that, the focus on utility maximization entails perceiving human beings as socially isolated ones, thereby denies the fact that individuals are influenced by others as well as by ethical and social norms ${ }^{17}$.

All the shortcomings and faults of neoclassical model fuel the discussion about an adequate understanding of the human actor in ecological economics. New, alternative conceptions that have emerged within this dispute focus on different human features and represent interdisciplinary, holistic approach to explaining sustainable behaviors.

\section{New human concept -overview of proposals}

Ecological economists call for introducing new, underlying conception of humans but it not necessarily means that replacing neoclassical model is an easy task. It is evidenced by both the number of new propositions and their diversity, and leads to the conclusion that none of the new conceptual frameworks of human actor has met the requirement of exhaustive explanation the principles of sustainable society so far. This lack of one, commonly accepted model is also a kind of consequence of interdisciplinary nature of ecological economics ${ }^{18}$. EE incorporates not only economic insights but also accomplishments of social psychology, ethics, philosophy, anthropology, ecology, evolutionary biology or even neuroscience.

The new human concepts emerging from the debates on sustainability can be analyzed from two different perspectives. First according to the time of their emergence, second according to the strength of their relationships with neoclassical thought ${ }^{19}$. In general scholars began to reveal their interest in elaboration of a new conceptual framework around year 2000. The initial conceptions were mostly a kind of amendments which had to supplement neoclassical model. The later notions were less tightly linked to homo oeconomicus and their authors introduced them as a replacement rather than just supplement to neoclassical notion.

\footnotetext{
${ }^{14}$ H. A. Simon: Theories of bounded rationality, [In:] Decision and Organization, Ed. C. B. McGuire, R. Radner, NORTH HOLLAND PUBLISHING Company, 1972.

${ }^{15}$ V. L. Smith: Constructivist and Ecological rationality in Economics, "The American Economic Review" vol. 93 no. $3 / 2003$, pp. $465-507$.

${ }^{16}$ O. Bina, S. Guedes Vaz: Humans, environment and economies: From vicious relationships to virtuous responsibility, "Ecological Economics" no. 72/2011, p. 171.

${ }^{17}$ B. Siebenhüner: Homo sustinens - toward a new conception of humans for the science of sustainability, "Ecological Economics" no. 32/2000, p. 17.

${ }^{18}$ I. Røpke: Trends in the Development of Ecological Economics from the Late 1980s to the Early 2000s, "Ecological Economics" no. 55/2005, pp. 262-290.

${ }^{19}$ In this paper we decided to introduce them in chronological order explaining the relationship with homo oeconomicus concept in case of each succeeding notion.
} 
The first new concept was described by Söderbaum ${ }^{20}$, who stated that in sustainable society a man should be perceived as political being. Contrary to neoclassical consumer who maximizes utility, Söderbaum's political economic person (PEP) is regarded as an actor playing many different roles and thus being embedded in a network of social relationships. In the same time he/she can both act in a socially responsible manner and follow his/her egoistic desires (altruistic motives don't exclude egoistic ones). Importantly PEP's lifestyle, which Söderbaum generally calls "ideological orientation" and which is driven by individual's convictions and ethical attitudes, may develop in more other-related (or more egoistic) direction with a lapse of time. Furthermore PEP doesn't behave in fully rational way as it is requested by neoclassical economists. Following the thought of behavioral economics Söderbaum acknowledges that human beings are often locked in the regime of their habits as well as they use various rules of thumb to deal with the complexity. Regardless of whether the certain behavior is more or less rational the individual's ideological orientation is of importance. Ultimately PEP is willing to change his/her ideological orientation or practical behavior, or both, to make them more compatible. Therefore Söderbaum underlines a crucial role of scientific and public debate to provide arguments for sustainability which will accordingly influence individual's value system.

Four further propositions of a new concept of human actor were published in 2000. Three of them were aimed at extending homo oeconomicus concept while assuming its importance in describing human behavior in certain circumstances. Accordingly, Nyborg put forward homo politicus notion (HP) ${ }^{21}$. This concept posits that every person has two distinct scales of preferences. When individual considers herself as a consumer she strives to maximize utility thus behaves in line with neoclassical model. If certain circumstances indicate that a citizen role is the most relevant, the person would behave in a way that maximizes social welfare (places public interest above the private one). To describe human being who lives in line with requirements of sustainability Siebenhüner has coined the name homo sustinents $(\mathrm{HS})^{22}$. Drawing inspiration from evolutionary biology, neurobiology and psychology this author claims that the incentives described by neoclassical economists are not the only driving forces for $\mathrm{HS}$. He/she is also guided by the strong emotional relationship with nature, the need of social communication and the sense of personal responsibility. Consequently the same features and skills that allowed humanity to evolve over the years make individuals to behave in sustainable way even despite their tendency to focus solely on self-interest. The next, complementary to homo oeconomicus, conception was introduced by Gintis $^{23}$. Inspired by insights of experimental economics this author proposed a new view on the self-interest notion. According to his model of homo reciprocans (HR) in some circumstances people are strong reciprocators who come to strategic interactions with a propensity to cooperate and respond to cooperative behaviors by maintaining or even increasing cooperation. Furthermore, in case of dealing with noncooperative free-riders individuals tend to

\footnotetext{
${ }^{20}$ P. Söderbaum: Values..., op. cit., pp. 160-171.

${ }^{21}$ K. Nyborg: Homo economicus and homo politicus: interpretation and aggregation of environmental values, "Journal of Economic Behavior \& Organization" no. 42/2000, pp. 305-322.

${ }^{22}$ B. Siebenhüner: Homo sustinens..., op. cit., pp. 15-25.

${ }^{23}$ H. Gintis: Beyond Homo Economicus: evidence from experimental economics, "Ecological Economics" no. 35/2000, pp. 311-322.
} 
retaliate against them even at a personal cost, and even when there is no reasonable expectation that such a retaliation will bring any personal gains in the future. In consequence individuals are willing to involve into sustainable actions if only they are convinced that it may bring advantage not only to the whole humanity but (in particular) to them personally. In contrary to the other concepts published in 2000, Jager et al. intended to replace homo oeconomicus model rather than simple extend it. Their proposition called homo psychologicus (HPS) arose as a result of applying the method of multi-agent simulation ${ }^{24}$. Using consumant approach these authors assumed that while making decisions people use not only deliberation (as a cognitive strategy) but also heuristics connected with social influences ie. social comparison, repetition and imitation. The differences between homo oeconomicus and homo psychologicus allowed them to conclude that the incorporation of a micro-level perspective on human behavior within integrated models of the environment yields a better understanding and eventual management of the processes involved in environmental degradation.

The authors of two subsequent concepts came back to the idea of extending neoclassical model. Referring to homo oeconomicus as well as criticizing it and all other concepts Faber et al. decided to embed their proposition in political philosophy and named it homo politicus (FHP) ${ }^{25}$. Furthermore they used case study method to prove FHP empirically. Faber et al. similar to Nyborg $^{26}$ defined FHP as a person who try to consider what is the best for society, but they differently perceived his/her engagement. Their homo politicus represents someone who is concerned with the public interest as well as a good of the community. Consequently he strives for political justice which in its intra- and intergenerational dimension provides the prerequisite of sustainability. In 2006 Becker, invoking to the natural relation between human beings and nature, introduced the notion of homo ecologicus $(\mathrm{HE})^{27}$. This concept is based on three human's features. First Backer assumes that individual refers to the nature with sympathy and respect. Second he describes individuals as creative entities who pattern their creativity on nature. Third he posits that the relation with nature derives from personal experience and encounter with it. Becker not only explains HE concept but also calls for building the one, comprehensive conception that would reflect all the important dimensions of sustainability and combine all the discussed models of human being. He stresses that the ultimate model should also draw from neoclassical notion because it correctly explains a short-term impact of economic incentives.

In 2010 Becker put forward another notion and called it sustainable person (SP) ${ }^{28}$. Although SP more resembles an overall ethical vision than represents precise model of human being, a general understanding provided by Becker allows to see sustainable person as an emotional, rational, communicative and creative entity. Simultaneously in

${ }^{24}$ W. Jager, M.A. Janssen, H.J.M. De Vries, J. De Greef, C.A.J. Vlek: Behaviour in commons dilemmas: Homo economicus and Homo psychologicus in an ecological-economic model, "Ecological Economics" no. 35/2000, pp. 357-379.

${ }^{25}$ M. Faber, T. Petersen, J. Schiller: Homo oeconomicus and homo politicus in Ecological.Economics, "Ebological Economics" no. 40/2002, pp. 323-333.

${ }^{26}$ K. Nyborg: Homo economicus..., op. cit., p. 310.

${ }^{27}$ Ch. Becker: The human actor in ecological economics: Philosophical approach and research perspectives, "Ecological Economics" no. 60/2006, pp. 17-23.

${ }^{28} \mathrm{Ch}$. Becker: Sustainability Ethics, 2010, http://ssrn.com/abstract=1626013 [accessed: 1.03.2016]. 
this case rationality is understood as a broad concept including practical wisdom and reason.

The authors of the next concepts strove to meet the challenge pointed by Becker by submitting such a conceptual framework that could finally replace homo oeconomicus. In 2013 Ferraro and Reid proposed homo faber (HF) ${ }^{29}$. This idea brings to sustainability debate a fundamental yet long neglected dimension of human experience. Furthermore introducing the aspect of materiality helps to soften the anthropocentrism that used to characterize human relationship with nature imposed by neoclassical economics. HF may be described as a person who focus on creating instead on consuming things, and this process of making is a main source of his life satisfaction. According to Ferraro and Reid in the scale of whole society drawing attention on making and its ethos can provide encouragement to move away of hedonistic consumption. Thereby HF may potentially promote a decrease in overall consumption levels what stays in line with sustainability objectives.

The distinct and thus very interesting approach to the problem of redefinition human actor in sake of sustainable development has been introduced by Menzel ${ }^{30}$. Instead of asking the question why people tend to behave in sustainable way, she deliberates what makes them to behave unsustainably. Furthermore, while summarizing the accomplishments of previous models she notices that they often represent morally better, nobler or more sustainable concepts of humans. In her opinion both the focus on such features as altruism, reciprocity or propensity to cooperative behaviors, and a fact that new concepts continue to emphasis on analytic or deliberative mental processes, make them out of touch of reality. To explain the phenomenon of human actor in sustainable society Menzel employs the insights from behavioral economics and neurology and argues that the interaction between so-called rational and emotional factors is crucial for understanding unsustainable behavior. This statement is based on the notion of dualprocess models ${ }^{31}$. According to them, while making decisions our brain employs two different computational processes labeled by Stanovich as System 1 and System $2^{32}$. Evolutionarily older System 1 is intuitive, quick, emotional, and is meant to response automatically, habitually and even unconsciously. System 2 is analytical, deliberative and conscious, thus responds slower and depends on individual's cognitive abilities and working memory ${ }^{33}$. Consequently any behavior should be seen as an effect of applying System 1 or System 2, or both systems working subsequently one after the other dependently on the complexity of the decision task. Referring to these mechanisms

\footnotetext{
${ }^{29}$ E. Ferraro, L. Reid: On sustainability and materiality. Homo faber, a new approach, "Ecological Economics" no. $96 / 2013$, pp. $125-131$.

${ }^{30}$ S. Menzel: Are emotions to blame? - The impact of non-analytical information processing on decisionmaking and implications for fostering sustainability, "Ecological Economics" no. 96/2013, pp. 71-78.

${ }^{31}$ In all honesty, we must admit that few references to dual-process models have been already incorporated in the previous works, but all the mentioned authors treated them as a secondary path of their deliberations.

${ }^{32}$ K. E. Stanovich: Who is rational? Studies of Individual Differences in Reasoning. PSYCHOLOGY PRESS, ROUTLEGE, TAYLOR\&FRANCIS GROUP, New York, London 2011, p. 144.

${ }^{33}$ S. Frederick, D. Kahneman: Representativeness revisited: Attribute substitution in intuitive judgment. [In:] Heuristics of Intuitive Judgment: Extensions and Applications. Ed. T. Gilovich, D. Griffin, D. Kahneman, CAMBRIDGE UNIVERSITY PRESS, New York 2002, pp. 51-52; K. Frankish, J. Evans: The duality of mind: An historical perspective. [In:] In two minds: Dual processes and beyond, Ed. J. Evans, K. Frankish, OXFORD UNIVERSITY PRESS, New York, 2009, p. 1.
} 
Menzel perceives unsustainable behavior as the result of two overlapping "rationales" and posits that people often use rationalization as a self-defense tool after making intuitive or emotionally driven decisions ${ }^{34}$. She concludes that emotions and intuitions are key drivers in sustainable society, because unsustainable choices emerge when: contra-sustainable intuitions or immediate desires are stronger than pro-sustainable reasoning, pro-sustainable intuitions doesn't exist or are dominated by stronger contrasustainable ones, deliberation processes reveals that positive effects of choosing more sustainable option are exceeded by direct personal benefits derived from choosing less sustainable alternative $\mathrm{e}^{35}$, emotions that encourage sustainable action are weaker than cognition which points toward less sustainable choice.

\section{Conclusions}

The introduction of the notion of sustainable development significantly changed the point of view on many economic problems which no longer can be overcome by applying well known concepts of neoclassical approach e.g. homo oeconomicus model. In fact the urgent need of finding the explanation of human behaviors in sustainable society became one of the most significant challenges faced by ecological economists.

Since the beginning of XXI century numerous attempts have been made to either supplement or replace neoclassical conception of human actor. Their authors concentrated on such issues as: social and political engagement, striving for political justice, altruism, ethical evaluating, communication abilities, reciprocity, propensity to cooperate, relationships with nature, creativity as well as applying heuristics, social comparisons, intuition, emotions and rationalization of emotionally made decisions. Although the ongoing process of searching for a new concept of human didn't bring any commonly accepted explanation yet, there is a clear tendency of looking at the individuals through the lenses of behavioral economics. Simultaneously the outcomes in this field are of the crucial importance to sustainable development policy. It may turn out that at least part of its inefficiency derives from the fact that sustainability rules are promoted mainly by rational reasoning, whereas they should also incorporate emotional message.

\section{Bibliography}

Agenda 21, https://sustainabledevelopment.un.org/content/documents/Agenda21.pdf [accessed: 25.01.2017]. Becker Ch.: The human actor in ecological economics: Philosophical approach and research perspectives, Ecological Economics 60/2006.

Becker Ch.: Sustainability Ethics, 2010, http://ssrn.com/abstract=1626013 [accessed: 1.03.2016].

Bina O., Guedes Vaz S.: Humans, environment and economies: From vicious relationships to virtuous responsibility, Ecological Economics 72/2011.

Chatzidakis A., Hibbert S., Smith A. P.: Why people don't take their concerns about fair trade to the supermarket: The role of neutralization, Journal of Business Ethics 74/2007.

Daly H.E., Farley J.: Ecological Economics. Principles and Applications, ISLAND PRESS, Washington DC 2004.

${ }^{34}$ E. Jones: Rationalisation in every-day life, "The Journal of Abnormal Psychology" vol. 3 no. 3/1908, pp. 166; A. Chatzidakis, S. Hibbert, A. P. Smith: Why people don't take their concerns about fair trade to the supermarket: The role of neutralization, "Journal of Business Ethics" vol. 74/2007, pp. 89.

${ }^{35}$ In fact this is the only case which corresponds to the nature of homo oeconomicus. 
Esterlin R. A.: Will Raising the Incomes of all Increase the Happiness of All? Journal of Economic Behavior and Organization 27/1995.

Faber M., Petersen T., Schiller J.: Homo oeconomicus and homo politicus in Ecological.Economics, Ecological Economics 40/2002.

Ferraro E., Reid L.: On sustainability and materiality. Homo faber, a new approach, Ecological Economics 96/2013.

Frankish K., Evans J.: The duality of mind: An historical perspective, [In:] In two minds: Dual processes and beyond, Ed. J. Evans, K. Frankish, OXFORD UNIVERSITY PRESS, New York, 2009.

Frederick S., Kahneman D.: Representativeness revisited: Attribute substitution in intuitive judgment, [In:] Heuristics of Intuitive Judgment: Extensions and Applications, Ed. T. Gilovich, D. Griffin, D. Kahneman, CAMBRIDGE UNIVERSITY PRESS, New York 2002.

Gendron C.: Beyond Environmental and Ecological Economics: Proposal for an Economic Sociology of the Environment, Ecological Economics 105/2014.

Gintis H.: Beyond Homo Economicus: evidence from experimental economics, Ecological Economics $35 / 2000$.

Jager W., Janssen M.A., De Vries H.J.M., De Greef J., Vlek C.A.J.: Behaviour in commons dilemmas: Homo economicus and Homo psychologicus in an ecological-economic model, Ecological Economics 35/2000.

Jones E.: Rationalisation in every-day life, The Journal of Abnormal Psychology vol. 3 no. 3/1908.

Kirman A.: Is it rational to have rational expectations? Mind \& Society 13/2014.

Kraciuk J.: Paradygmat homo oeconomicus w aspekcie rozwoju ekonomii heterodoksyjnej, Prace Naukowe Uniwersytetu Ekonomicznego We Wrocławiu. Ekonomia 401/2015.

Meadows D. H., Meadows D. L., Randers J., Behrens W.: The Limits to Growth, UNIVERSE BOOKS, New York 1972.

Menzel S.: Are emotions to blame? - The impact of non-analytical information processing on decisionmaking and implications for fostering sustainability, Ecological Economics 96/2013.

Munda G.: Environmental Economics, Ecological Economics, and the Concept of Sustainable Development, Environmental Values 6/1997.

Muth J. F.: Rational Expectations and the Theory of Price Movements, Econometrica, vol. 29 no. 3/1961.

Nyborg K.: Homo economicus and homo politicus: interpretation and aggregation of environmental values, Journal of Economic Behavior \& Organization 42/2000.

Røpke I.: The early history of modern ecological economics, Ecological Economics 50/2004.

Røpke I.: Trends in the Development of Ecological Economics from the Late 1980s to the Early 2000s, Ecological Economics 55/2005.

Schiliro D.: Bounded rationality: Psychology, economics and the financial crises, Theoretical and Practical Research in Economic Fields vol. IV issue 1(7)/2013.

Siebenhüner B.: Homo sustinens - toward a new conception of humans for the science of sustainability, Ecological Economics 32/2000.

Simon H. A.: Theories of bounded rationality, [In:] Decision and Organization, Ed. C. B. McGuire, R. Radner, NORTH HOLLAND PUBLISHING COMPANY 1972.

Smith A.: The Theory of Moral Sentiments, DOVER PUBLICATIONS, INC Mineola, New York 2012, https://books.google.pl/books?id=2iV_vnHmdUEC\&printsec $=$ frontcover\&hl $=\mathrm{pl} \# \mathrm{v}=$ onepage\&q\&f $[$ accssesed: 24.02.2017].

Smith V. L.: Constructivist and Ecological rationality in Economics, The American Economic Review vol. 93 no. $3 / 2003$.

Söderbaum P.: Values, ideology and politics in ecological economics, Ecological Economics 28/1999.

Spash C. L.: Social Ecological Economics: Understanding the Past to See the Future, American Journal of Economics and Sociology vol. 70 no. 2/2011.

Stanovich K. E.: Who is rational? Studies of Individual Differences in Reasoning, PSYCHOLOGY PRESS, ROUTLEGE, TAYLOR\&FRANCIS GROUP, New York, London 2011.

Waring T.M.: New Evolutionary Foundations: Theoretical Requirements for a Science of Sustainability, Ecological Economics 69/2010. 


\section{Summary}

The way in which economists perceive and interpret human behaviors directly translates into the tools of sustainable development policy (SDP). The efficacy of these tools, hence the possibility of attaining sustainable development (SD) goals depends on how precisely the background assumptions reflect mechanisms of human behaviors. Along with a maturation of sustainability concept it was becoming obvious for ecological economists that this condition is no longer fulfilled by neoclassical concept of homo oeconomicus. According to this path of thought the neoclassical model neither reflects the rules of sustainable society nor explains sustainable behaviors of individual actors. In consequence, ecological economists have been focused on the analysis and critique of homo oeconomicus model. They also started to search for a new concept which would be able to either complement or replace it. This article seeks to explain the vital points of critique of homo oeconomicus concept and, on this background, to describe new concepts introduced by the opponents of neoclassical approach.

Key words: conception of humans, ecological economics, sustainability, homo oeconomicus

Information about the author:

Dr Jolanta Zralek

Katedra Badań Konsumpcji

Wydział Zarządzania

Uniwersytet Ekonomiczny w Katowicach

ul. Bogucicka 14

40-226, Katowice

tel. (32) 2577561

e-mail: jolanta.zralek@ue.katowice.pl 